\title{
Covert Political Conflict in Organizations: Challenges from Below
}

\author{
Calvin M orrill, ${ }^{1}$ Mayer N. Zald, ${ }^{2}$ and Hayagreeva Rao ${ }^{3}$ \\ ${ }^{I}$ Department of Sociology, University of California, Irvine, California 92697-5100; \\ email: calvin@uci.edu \\ ${ }^{2}$ Department of Sociology, University of Michigan, Ann Arbor, Michigan 48109-1382; \\ email:mayerz@umich.edu \\ ${ }^{3}$ Kellogg School of Management, Northwestern University, Evanston, Illinois 60208; \\ email: hayagreeva-rao@kellogg.northwestern.edu
}

Key Words collective action, social movements, sabotage

- Abstract This review considers a class of political activity that has largely been ignored by researchers extending social movement theory into organizations: covert political conflict. Although much of the literature we discuss focuses on contemporary corporations where the bulk of research on covert conflict has occurred, we also explore studies of covert conflict in a range of historical and organizational contexts that fall outside the contemporary work world. As we define it, covert political conflict encompasses four interrelated elements: contestation of institutionalized power and authority, perceptions of collective injury, social occlusion, and officially forbidden forms of dissent. Beyond these elements, covert conflict varies in its material and symbolic forms, collective dimensions, social visibility, and outcomes. We also examine explanatory approaches for covert conflict at the micro, organizational, field, and macro levels of analysis. Finally, we suggest a number of areas for future research on covert conflict that include developing theoretical frameworks across multiple levels of analysis, stronger linkages between organization theory and the study of covert conflict, strategies for measuring outcomes (including the emergence of overt political voice and organizational change), and new methods for empirical inquiry.

\section{INTRODUCTION}

During the past decade, sociologists increasingly drew on social movement theory to understand change in a broad array of organizations: economic corporations (Davis \& Thompson 1994, McCann 1994, Scully \& Segal 2002), governmental bureaucracies (Katzenstein 1998, Zhou 1992), interest groups and political parties (Clemens 1997, Zhou 1992), religious institutions (Ammerman 1990, Chaves 1997, Kurzman 1997), emergent professional associations (Morrill 2003, Morrill \& Owen-Smith 2002), and consumer agencies (Rao 1998). Zald \& Berger (1978) provided an early exemplar with their analyses of "mass movements," 
"bureaucratic insurgencies," and "coup d'etats" in American corporations. More recently, Davis \& McAdam (2000) argued that the globalized decline of the mass production paradigm and economies rooted in managerialist ideology renders conventional organization theory inadequate by itself for investigating how contemporary social forces have transformed workplaces. Social movement theory, they maintain, offers a useful conceptual vocabulary for understanding the new social structures wrought by transitory global production, volatile financial markets, and transnational collective action and governance. Rao et al. (2000) build on these insights by demonstrating the role of collective action and social movements in the creation of new organizational forms and fields of practice.

Bringing social movement theory into organizational research has yielded undeniably useful insights into organizations. Yet, this theoretical innovation suffers from a narrow focus on open confrontation that overlooks a range of political action simmering beneath the surface of mass mobilizations and other movementlike phenomena. Conflict of this sort is often overlooked because it is usually not viewed as "politics" in the conventional sense, instead it is labeled as opportunistic criminal behavior (Taylor \& Walton 1971) or the work of isolated, disgruntled individuals (Jermier 1988). Moreover, the injustices that fuel such conflict typically fall outside the realms of legal and conventional extrajudicial complaint handling mechanisms (e.g., Nader 1980). Yet, as Scott (1989; for organizations, see Kolb \& Putnam 1992, Lammers 1969) vividly demonstrates for covert political conflict, more generally, such action is a "vital means" by which subordinated groups express their political grievances against superiors, displaying tacit, if not explicit, coordination and various forms of group solidarity. By contrast, organizational elites and superiors typically deploy formally structured instruments of control as they engage in political struggles with subordinates (Arvey \& Jones 1985, Baumgartner 1984).

What is missing in the literature is a more coherent vision of covert political conflict with regards to its conceptual foundations, empirical findings, and linkages to overt political voice in organizations. In the ensuing pages, we address these shortcomings with particular reference to challenges by subordinates in capitalist workplaces where the bulk of research on covert conflict has been conducted. We organize our review around three broad questions: First, how can covert political action be conceptualized such that it aids research on political processes of organizational change? To answer this question, we briefly outline the constitutive elements that define covert political opposition. Second, what variable aspects of covert political action have been identified? We answer this question by discussing material and symbolic forms of covert political action, as well as variation in social visibility, collective dimensions, and outcomes. Third, under what conditions will covert political conflict occur? Here we explore explanations for covert conflict at the micro, organizational, field, and macro levels of analysis. This last section comes full circle as we link covert political conflict with explicit voice, thus deepening the sense of complex organizations as "contested terrains" (Edwards 1982) over control and broadening the processes through which social power can be 
expressed. This last section also leads to a final summary and a brief outline of implications and potentially fruitful areas for future inquiry.

\section{CONSTITUTIVE ELEMENTS OF COVERT POLITICAL CONFLICT}

We define political conflict as a form of "contentious politics" in which challengers contest authorities over the "shape" and governance of "institutionalized systems of power" (McAdam et al. 2001, pp. 342-43). This definition focuses on how the dynamics of interaction constitute political conflict and recognizes that such opposition in organizations need not directly involve states but can challenge authority based in formal authority structures, culture, or other social arrangements (Snow 2002). Such challenges are often embedded, either implicitly or explicitly, in broad social cleavages and power inequities, including those between capital and labor, shareholders and managers, members of different status and identity groups (e.g., women and men, gays, ethnic minorities), and elites vying for power (Jermier et al. 1994b). At the same time, research on covert conflict resonates with earlier organizational approaches to "micro politics" (Burns 1955, 1961; Mechanic 1962), organizational "trouble" (Emerson \& Messinger 1977), coalition formation (Dalton 1959), and decision-making power (Petigrew 1973, Pfeffer 1981, Zald 1970). Most importantly, the study of covert dissent underscores Zald \& Berger's (1978) conceptualization of organizations as "polities" with interest groups, distributions of right and duties, and governance systems.

The presence of enduring cleavages in organizational polities, however, is insufficient to define or fuel conflict without some sense of collective injury (Tucker 1993) or "justice motive" (Nader 1980). The meanings that such perceptions can carry are nearly always negotiated in informal and unseen ways by participants and various social audiences. At the outset, actors may have difficulty locating the sources of their injuries, assessing blame, or making claims about appropriate remedies (Felstiner et al. 1980/1981) and may turn to collective action "master frames" for help in making sense of their troubles (Snow \& Benford 1992). Moreover, blurred boundaries can exist between covert conflict in terms of its pro- and/or antiorganizational footings. Meyerson's (2001, see also Meyerson \& Scully 1995) work on "tempered radicals" illustrates this tendency. Tempered radicals are individuals who "contribute and succeed at their jobs ... but who are considered outsiders because they represent ideals or agendas that are . . at odds with the dominant culture" (Meyerson 2001, p. 5). Tempered radicals thus uphold their identities as insiders but push hard to change the system that casts them as outsiders. Once blame is subjectively assessed, there can still be enormous gulfs between perception, collective action, and identifiable outcomes as social movement theory underscores (Snow \& Benford 1992). Organizational authorities can directly interrupt this process, should they discover it, by suppressing wouldbe activists as deviants (Taylor \& Walton 1971). Moreover, covert conflict can 
become implicated in interpersonal squabbles (Clarke 1988, Greenhalgh 1987) and the broader "underlife" of organizations, as Goffman (1962) called it, creating further ambiguities about its scope and nature.

In addition to the elements discussed above, covert political conflict must avert the detection and direct engagement of various social audiences, especially elites and other authorities. By remaining veiled, such action can appear nonthreatening or may even be ignored by elites until its impacts become undeniably apparent. As a result, covert political conflict can remain hidden for long periods of time, offering relative safety for those involved, thus enabling its diffusion and development. The occluded nature of covert political conflict is particularly salient because such opposition typically involves strategies to pursue grievances that are unprecedented or forbidden by the organization in question. Beyond these constitutive elements, covert political conflict also varies in terms of its forms, social visibility, collective dimensions, and outcomes. We discuss these features in the next section.

\section{VARIABLE FEATURES OF COVERT POLITICAL CONFLICT}

\section{Material and Symbolic Forms}

By form, we mean the general properties inherent in a pattern of covert opposition, with particular emphasis placed on the primary means and aspects of an organization targeted for subversion. Scott (1989) provides a suggestive lead for classifying covert political conflict by drawing attention to whether it focuses on the material or symbolic aspects of social institutions. In organizations, "material" forms focus on the subversion (and often the destruction, hampering, or appropriation) of organizational technologies and resources, whereas "symbolic" forms attempt to subvert dominant meanings, ideologies, and discourses.

In practice, the material and symbolic aspects of covert forms can be intertwined and negotiated among various constituencies over time (Bayat 1997). The meanings of a single act of sabotage can sometimes take years to fully unfold or be recognized. Similarly, different kinds of accounts can emerge to explain an act of covert conflict before, during, and after its occurrence. As a result, it may be more appropriate to conceive of material and symbolic forms as existing in overlapping Venn diagrams, with most forms exhibiting tendencies toward one side of the diagram or the other. In fact, many studies of covert conflict reviewed here find that participants tend to accent the material or symbolic aspects of their actions. We follow this tendency in our discussion in this section, although we note along the way forms that tend to mix the material and the symbolic.

MATERIAL FORMS Sabotage and theft have dominated covert conflict research agendas. Some researchers define sabotage as any behavior that deliberately undermines organizational goals (Brown 1977) or restricts output and/or reduces the quality of goods (Dubois 1979). LaNuez \& Jermier (1994, p. 221) more precisely characterize sabotage as "any deliberate action or inaction that is intended 
to damage, destroy, or disrupt some aspect of the workplace environment, including the organizations's property, product, or reputation." LaNuez \& Jermier (1994, p.241) offer an additionally useful distinction between "sabotage by direct action" and "sabotage by circumvention." The former describes behaviors that directly "damage or destroy organizational property or products," whereas the latter refers to actions that facilitate other events or situations that eventually harm an organization.

Of these two subtypes, sabotage by direct action in mass production factories is the most commonly studied, especially those drawing from neo-Marxist perspectives to study resistance in the labor process (LaNuez \& Jermier 1994). Examples of direct sabotage include misassembling and omitting parts to produce high numbers of "reject" engines in a Detroit automobile factory (Watson 1971), damaging parts in a San Francisco-area automobile manufacturer (King 1978), breaking tools and machinery in a Midwestern electronic components factory (Fennell 1976), "arranging" machine breakdowns in a commercial bakery (Ditton 1979), breaking conveyor belts in a slaughterhouse (Thompson 1983), and surreptitiously breaking machines and electronic components in Japanese-owned Malaysian factories (Ong 1987). Historically, both the Luddites and the Wobblies engaged in direct material sabotage of manufacturing plants. In all of these cases, authors report some sense of collective injury held by saboteurs. Such injuries range from being collectively ignored in crucial decisions at the point of production (Watson 1971) to being denied basic human comforts on the shop floor (Ong 1987) or having an entire way of life destroyed by changes in the labor process (Jermier 1988). Although the material aspects of direct sabotage are emphasized in these works, some studies demonstrate how sabotage acts as a "symbolic gesture against the brutality of factory life" (LaNuez \& Jermier 1994, p. 224) by asserting the dignity and self-worth of workers. Among these works are participant observation studies of slaughterhouse workers (Thompson 1983) and brewery workers (Molstad 1986).

Other types of organizations and work, however, are not immune to direct sabotage. Computerization provides a myriad of opportunities for direct sabotage, including unleashing computer viruses, erasing files, or not saving files appropriately (Gialcone \& Greenberg 1997, Gilliom 1997, Gottfried \& Fasenfest 1984). Researchers also report mental health workers defacing and debilitating property in mental wards to "protest" managerial practices (Spector 1975), construction workers breaking tools on construction sites to express their discontent with their working conditions (Tucker 1993), and civil servants in public bureacracies who subvert various policies (Brehm \& Gates 1997).

Forced labor in a variety of historical and cultural contexts provides the occasion for direct sabotage as well. A case in point comes from indentured servants in seventeenth-century New England households who resisted their master's impositions by defiling food and other goods (Morgan 1966). Aggrieved peasants on eighteenth-century Polish manors reduced the "intensity" of their work and intentionally built structures that collapsed once completed (Kochanowicz 1989). North and South American slaves in the seventeenth through nineteenth centuries 
engaged in collective destruction of valued resources-including killing fellow slaves - as a means to resist their masters' domination (Baumgartner 1984). In the European-held colonies of the nineteenth and twentieth centuries, Guha (1989) reports the destruction of resources by indigenous peoples "statutorily" required to work under horrid conditions in colonial organizations.

Noncooperation with respect to organizational rules and procedures and/or superiors is perhaps the most common technique of sabotage by circumvention (Prasad \& Pushkala 1998, Rusbult \& Lowry 1985, Rusbult et al. 1988). Eldrige (1968), for instance, reports patterns of strategic "inaction" among British steelworkers intended to counter technologically reduced worker control and decision making at the point of production. So subtle were their actions that management blamed the new technology, rather than the workers, for production snafus. Poignant historical illustrations of noncooperation can be found among early twentieth-century English day laborers (Howkins 1977), Polish workers in Nazirun organizations during World War II (Gross 1979), farm hands on governmentowned Nicaraguan farms (Colburn 1989), factory workers during August Pinochet's Chilean regime (J. Stillerman 1998, unpublished dissertation), and migrant workers in the aftermath of the Iranian revolution in the 1970s (Bayat 1997). All of these types of noncooperation involve not meeting organizational or overseer expectations. A more subtle type involves "working to rule" in which workers meet official procedures to the letter without exercising necessary discretion. Their actions in turn lead to production breakdowns and/or compromises in product quality (Eldrige 1968, Gottfried 1994).

Sabotage by circumvention, however, is not confined to lower-status members of organizations. A nonrandom survey from the late 1980s of 400 American managers found that one third of those surveyed admitted to withholding information needed for key decision making or not including key personnel in decision making in order to deleteriously affect the quality of the choices made (LaNuez \& Jermier 1994). "Open mouth" sabotage is yet another type of sabotage by circumvention that can be directed to a number of constituencies, including competitors, customers, employees, and regulators (Knights \& McCabe 1998a, LaNuez \& Jermier 1994). Among the examples found in the literature are incidents of workers leaking information about "shoddy" production to the press or managers passing proprietary secrets to competitors (Jermier 1988).

Whereas sabotage involves harming organizational resources in direct and/or indirect ways, theft requires the appropriation of property by aggrieved parties. Justice-motivated sabotage and theft also differ in their underlying logics. Sabotage often carries a "penal" logic in which harming the organization punishes superiors for their transgressions, whereas theft compensates subordinates for wages and other material resources they believe superiors have unjustly denied them (Baumgartner 1984, Tucker 1989). In a survey of 5000 respondents across retailing, health, and manufacturing industries, Hollinger \& Clark (1982, p. 142) found that "employees who felt exploited by their company or by their superiors" used theft as one of their prime strategies to right such injustices. Theft of this sort 
has been documented among a wide range of occupations, including dockworkers (Mars 1974, 1982), miners (Gouldner 1954), sales personnel (Zeitlin 1971), accountants (Cressey 1953), and managers (Willis 1986). At the same time, the boundaries between legitimate property appropriation and theft can be ambiguous: Pilfering is sometimes officially built into organizational control systems to make up for wage deficiencies (Ditton 1977, p. 48).

Compensatory theft not ordained by organizations has also been studied across occupations and organizations in a broad range of historical contexts. Hall (1952), for instance, recounted Aristotle's complaints about Athenian road commissioners who embezzled funds when they believed they were cheated by their superiors. Hanawalt (1979, p. 179) describes a thirteenth-century English case in which four peasants stole grain from the Abbot of Ramsey's barn. They believed their theft compensated them for the insufficient bread the Abbot supplied them while working on his land. Similar episodes can be found in "filching" by eighteenthcentury Russian house serfs against "unfair" masters (Blum 1961), "swindling" committed by Danish peasants against landlords (Rockwell 1974), and theft by workers in nineteenth-century English cotton mills (Tobias 1972). Forced labor in countries militarily occupied also provides moral justifications for theft by workers (Gross 1979).

SYMBOLIC FORMS Scholars have devoted less attention to the symbolic side of covert political conflict in organizations, although there is little evidence to suggest that symbolic forms occur less frequently than material forms (Goffman 1967, Scott 1989). Some of the reasons why fewer scholars have studied symbolic covert conflict include difficulties in its definition and detection, as well as difficulties in gauging its outcomes. Although an act of property destruction can provoke deliberations about its meaning (e.g., "Was it sabotage, incompetence, unavoidable, or some combination of all three?"), one is left with a damaged machine or depleted resources as a clue to what happened. The residue of symbolic covert conflict can be more subtle and thus harder to identify and analyze. Another limiting factor may be the inordinate attention devoted to factory workers on assembly lines by labor process scholars who regard material sabotage as a key resistance strategy to capitalist discipline (Jermier 1988).

Consider Goffman's (1967, p. 58) observations on subversion in face-to-face interaction: "By easily showing a regard that he does not have, the actor can ... insinuate all kinds of disregard by carefully modifying intonation, pronunciation, pacing, and so forth." Such processes can certainly express personal enmity that is decoupled from political grievances. Yet they can also feed into subtle, parallel lines of individual political action as Martin \& Meyerson $(1997,1999)$ demonstrate in their research on "disorganized coaction." Female managers in the firm they studied rarely confronted male colleagues with grievances regarding their treatment as women in a masculine working environment. Instead, they adhered to masculine norms of interaction but sometimes engaged in acts of nonconformity that subverted the masculine interaction order. Men found these acts difficult to 
read because they were embedded in conformity to the dominant norms of interaction. Covert conflict of this sort has also been noted in service occupations (Paules 1991), mental hospitals (Goffman 1962), and among lower-status male executives in American corporations (Morrill 1995).

Another symbolic form-which we call symbolic escape-includes acts that aggrieved parties use to remove themselves from official organizational authority by carving out psychological, social, temporal, or physical niches in organizations. Symbolic escapists seek to reintroduce a measure of control into their lives that is beyond the reach of official routines they deem unfair or intolerable. Although these activities can be individualistic, such as daydreaming (Cohen \& Taylor 1993), they more often than not take on a collective nature. A prime example is taking extra break time to protest organizational policies while a colleague covers one's actions (Gottfried 1994, Knights \& McCabe 1998b). One of the most intriguing types of symbolic escape unfolds among Malaysian women working in Japaneseowned factories who "succumb" to mysterious "spirit possession" in the presence of overseers. Ong (1987) argues that women use these bouts of "hysteria" to escape capitalist discipline in the labor process. Earlier, Lewis (1971) argued that spirit possession thwarts male domination of Malaysian women's occupational and sexual identities by disrupting capitalist-patriarchal control systems and discourses. The aftermath of spirit possession can lead to managerial fears of contagion among women, costly factory shut downs, and hastily hired exorcists to perform "preventive" rites. It is unclear, however, how spirit possession leads to social change or how it affects the life chances and political consciousness of women.

Less ambiguous (at least to participants) are hidden transcripts that dissident subcultures generate (Scott 1989, 1990). Hidden transcripts develop backstage in the autonomous social spaces created by symbolic escape. In these spaces, subordinates spin tales of revenge, celebrate hero myths of those who stood up to exploitive superiors, and engage in discourses that underscore the inherent dignity of subordinates (Kanter 1977, Kunda 1992). Bies \& Tripp (1998, p. 213) provide a dramatic case-in-point in their study of workplace "carnivals" that employees hold in response to organizational "tyranny." At carnivals, "employees would demonize their bosses - that is, vent their frustrations, assign blame, call the bosses names (e.g., Beezelbub), and generally bad-mouth their bosses." Although not as colorful as carnivals, gossip functions as a hidden transcript that evaluates the normative behavior of absent individuals (Merry 1982). In some instances, gossip can even act as a symbolic "trial in absentia" of authority figures in which blame and remedies are assigned (Tucker 1993, p. 31). Gossip also strengthens the boundaries of backstage groups relative to other social actors (Wittek \& Wielers 1998), which in turn protects the development of future hidden transcripts (Hodson 1991). Hidden transcripts can also occur in the presence of superiors. Gottfried (1994, p. 119), for example, describes how female temporary workers interpret dress codes by wearing slacks rather than skirts to "resist prepackaged gendered identities" regarding secretarial support staff, all the while claiming ignorance about the rules. 
A final symbolic form is illustrated by ritualized confrontation, which feminist scholars argue carries the capacity to open up small fissures in male-dominated organizational power relations. For example, Martin \& Meyerson (1997, 1999) documented a case of ritualized confrontation in which a female executive in an American high-tech firm conformed to the masculine norms of direct confrontation by telling her boss "to go to hell" and, at the same time, disrupted "expectations of appropriate 'feminine' behavior, such as deference and avoidance of conflict" (1999, p. 336). Yet another example of ritual confrontation comes from Van Mannen's (1992) ethnography of an English police department. In the midst of pub parties, verbal ripostes between higher and lower ranks can take on a stylistic character and touch highly charged personal and policy issues. The covert nature of these conflicts occurs in their aftermath - the next day - as participants (especially lower ranks) claim they "were out of their minds" with alcohol (1992, pp. 50-51). The mixture of confrontation and occlusion in ritualized confrontation points to a second variable aspect of covert political conflict: social visibility.

\section{Social Visibility}

Social visibility can be thought of as the degree to which opposition political interests and actions (including the participants' identities) are known (especially to authorities). In the upper left quadrant of Figure 1, as illustrated by union strikes, participants and their interests are typically well-known to broad social audiences. In political conflict, collective interests are always something of a moving target, with their dynamics occurring on back and front stages. In covert politics, such interplay largely occurs behind the scenes (Haldeman 1994, Mahmood 2001). Perhaps the most common configuration of visibility with respect to covert conflict is represented by the lower left quadrant of Figure 1, where the collective

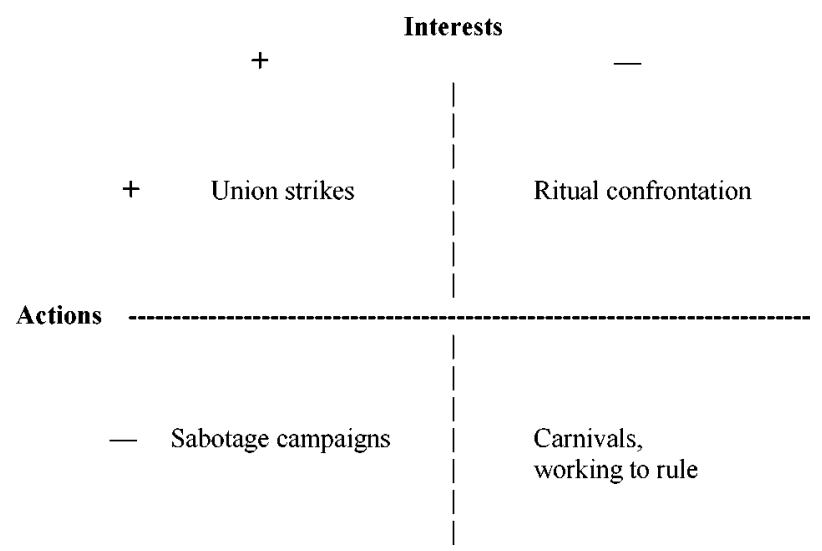

Figure 1 Social visibility covert political conflict in organizations. (Each quadrant contains a relevant illustration.) 
interests and intents of participants are known, but the times and places of their actions are unknown. As Scott (1989, p. 27) points out, covert actions of this sort send a signal of protest, yet are often concealed behind public conformity, as the nineteenth-century Luddite sabotage campaigns against English mills illustrate. Luddites maintained their daily work schedules while engaging in sabotage at night, which constrained authorities from learning when they would act or their individual identities (Jermier 1988).

As illustrated by ritualized confrontation (upper-right quadrant of Figure 1), the undercover nature of covert conflict can unfold through ambiguous actions that occur directly in the presence of the authorities without the latter knowing the interests involved. Finally, there are actions (represented in the lower-right quadrant of Figure 1), such as working to rule or employee carnivals, in which both interest and action are largely unseen by all except direct participants. Even if authorities discover such acts, their significance may be regarded as blowing off steam without their political implications being comprehended.

\section{Collective Dimensions}

Closely related to the social visibility of covert political conflict are its collective dimensions. Although some popular and industrial pundits (Crino \& Leap 1988, Curtius 1998, Vinzant 2000) and business scholars (Gialcone \& Greenberg 1997, Gialcone \& Knouse 1990) portray covert political conflict in organizations, especially sabotage, as the work of isolated misfits, much of the empirical research reviewed above suggests otherwise. Figure 2 represents the range of variation in the collective dimensions of covert political conflict. Close to the individualistic end of the continuum are seemingly solitary acts that nonetheless involve subtle collective aspects, as illustrated by disorganized coaction. At the opposite end of the continuum are formally coordinated actions, which are illustrated by the command and control structures in the Luddite sabotage campaigns (Jermier 1988). Far more prevalent are studies of covert conflict that fall somewhere between these two extremes. At one point is action in which colleagues tacitly comply with those engaged in covert activities, as illustrated by much of the justice-motivated theft discussed previously. As early as the eighteenth century, Jonathan Swift (quoted in Thomas 1999, p. 553), in his sardonic Directions to Servants, recognized this collective dimension of covert conflict among English servants: "If you see

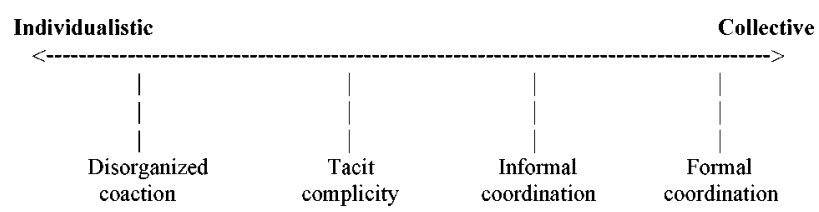

Figure 2 Collective dimensions of covert political conflict in organizations. 
your master wronged by any of your fellow-servants, be sure to conceal it." Even more prevalent within the literature is informally coordinated resistance networks (Fennell 1976) or "virtual groups" (Stephenson 1990) within and across organizations. Much of the material sabotage and hidden transcripts discussed previously are supported by networks and groups of these kinds.

\section{Outcomes}

A fourth way covert conflict varies is in terms of its outcomes. Few studies of covert opposition systematically conceptualize or measure its outcomes. Instead, researchers focus on the psychological relief enjoyed by participants or examine interpersonal "micro emancipation" that "break[s] away from diverse forms of oppression" (Alvesson \& Wilmott 1992, p. 447). Some studies, however, report the role of covert conflict in organizational change, including the disruption of unfair organizational routines (LaNuez \& Jermier 1994) and dominant gender identities (Martin \& Meyerson 1999, Sotirin \& Gottfried 1999). These studies suggest that covert conflict leads toward informal gains in which inequitable organizational practices and routines are questioned or subverted and constrained, rather than transformed.

Scott (1989) is perhaps the most optimistic about the outcomes covert conflict can produce in wider society, although he does not directly address his comments to organizations. He argues covert conflict can subtly prepare the way for largescale transformations " ... just as millions of anthozoan polyps create, willy-nilly, a coral reef, thousands upon thousands of petty acts of insubordination and evasion create a political and economic barrier reef of their own" (p. 20). This barrier reef is often constructed from the cultural transformation of understandings about what is unjust, what changes are possible, and how people can fight back covertly against injustice (Rochon 1997, p. 239). Applied to organizations, the long-term cultural readiness for overt political conflict may ultimately prove to be the most documented outcome of covert conflict even though the latter can ironically reproduce hegemony in the short term because its participants must cloak their activities in outward conformity to official policies and everyday routines.

Despite these speculations, the conditions under which covert collective action results in intensified mobilization among potential partisans, public voice, or significant changes in organizations remains an open question. Moreover, it is unclear, aside from some intriguing speculations, how covert political opposition in organizations is influenced by broad social movements or covert conflict (e.g., terrorist attacks) that become highly publicized.

\section{EXPLAINING COVERT CONFLICT IN ORGANIZATIONS}

We turn now to a discussion of the conditions that influence the occurrence and patterning of covert conflict. Researchers often downplay explanations for covert conflict, instead concentrating on thick descriptions of its existence and vibrance. 
This trend is understandable given the relative lack of visibility of covert conflict both empirically and in the literatures on organizational conflict, change, and collective action. As a result, theoretical explanations for covert conflict are fragmented across an array of work at the micro, organizational, field, and macro levels of analysis. The most developed perspectives focus on the micro level.

\section{Micro Level}

SOCIAL PSYCHOLOGICAL PERSPECTIVES Among the most prominent factors studied at the micro level are perceptions of declining control and frustration over the workplace. These factors operate as the chief social psychological mechanisms in research ranging from neo-Marxist studies of resistance in the labor process (Jermier et al. 1994a) to survey research on sabotage (Allen \& Greenberger 1980). Proponents of this approach argue that organizational members whose perceptions of their task control have dipped below preexisting, desired levels are most likely to engage in covert opposition (Greenberger et al. 1989). Such control can involve an array of issues, including planning (Eldridge 1968, Watson 1971), compensation systems (Edwards \& Scullion 1982), and temporal aspects of work, such as pace (Watson 1971) or break times (Ditton 1976, Gottfried \& Fasenfest 1984). Frustration associated with a declining sense of control has also been found to precede and/or correlate with organizational sabotage (LaNuez \& Jermier 1994, p. 225; Spector 1975).

Perhaps the most systematic program of social psychological research relevant to covert conflict draws from Hirschman's (1970) classic “exit, voice, and loyalty" typology (see the review in Dowding et al. 2000). Hirschman argued that people can either withdraw (exit) or express their grievances (voice) to a social organization (e.g., a market, a firm, a state) they define as deteriorating or unjust. One's commitment (loyalty) to the offending source modifies the choice between exit and voice, compelling people to withstand egregious conditions. In a series of studies, Farrell, Rusbult, and colleagues found loyalty (which they label investment) predicts voice, but that neglect (a form of noncooperation) is more likely when employees have long-term dissatisfaction with their jobs but little loyalty to their organizations (Farrell 1983, Farrell \& Rusbult 1992, Rusbult \& Lowery 1985, Rusbult et al. 1988). All these formulations portray exit as covert (relative to voice) and more likely when loyalty is low and alternative organizational membership is possible. Hirschman (1993) has questioned this characterization in light of highly visible mass exits from Eastern Europe during the late 1980s and well-known schisms in religious organizations.

SOCIAL INTERACTION, IDENTITY, AND INTERPERSONAL NETWORKS Social interaction and social identities significantly influence how people define conflict, the repertoires they have for handling conflict, and the outcomes they expect (Barley 1991, p. 175; Kolb 1987; Morrill 1995). LaNuez \& Jermier (1994, pp. 238-39), for instance, argue that middle managers who socially interact and identify more with 
superiors tend to develop "corporate social identities" with "low sabotage" potential. Managers who identify with their subordinates develop "worker identities" with "high sabotage potential."

The contents and forms of social networks can also influence covert opposition. Superiors and subordinates who enjoy social relationships with multiple substantive contents such as friendship and religion reduce the likelihood for covert conflict because they are more likely to identify with each other and develop trust that increases the likelihood of open negotiation (Morrill 1995, pp. 92-140). Intraorganizational social networks with dense-knit forms (in which organizational members interact with each other a great deal) can lead to overt conflict expressions, whereas loosely knit networks are associated with organizational exit and various forms of escape (Morrill 1991). Fennell (1976) reported that loosely knit networks across organizations can diffuse information about worker grievances and sustain covert sabotage.

\section{Organizational Level}

FORMAL STRUCTURE AND AUTHORITY At the organizational level, researchers have explicitly investigated the trade-offs between formal structures that encourage voice and those that discourage it. Zald \& Berger (1978, see also Morrill 1995), for example, argue that formal organizational hierarchies limit the opportunities for voice when compared to professional, voluntary, and federated associations. Such organizations contain flatter organizational structures that encourage various forms of voice in open polities, thus reducing covert political action. The relationship between formal structure, voice, and covert conflict is sometimes framed in terms of two competing predictions: the "substitution" ("balloon") or the "complimentarity" ("iceberg") hypothesis (Sapsford \& Turnbull 1994). The substitution hypothesis predicts formal structures that facilitate voice will reduce covert conflict (i.e., squeeze a filled balloon in one place and the air inside it expands outward in another location). The complementarity hypothesis predicts that formally enabling voice is associated with "corresponding increases in other forms of ... [submerged] conflict" (Sapsford \& Turnbull 1994, p. 250). Empirical research reveals support for the substitution hypothesis (Hebdon \& Stern 1998, Sapsford \& Turnbull 1994).

These perspectives also link concretely with various approaches to organizational power. As we noted at the outset of this essay, one of the core assumptions in the literature on covert conflict is that subordinates-particularly the disenfranchised - are the most likely to engage in hidden political opposition. However, power and resources do not simply affect whether one is able to express voice or not: They also shape definitions of what is and is not objectionable. Studies of interactions between professionals and nonprofessionals, for example, find that nonprofessionals tend to adopt the definition of conflict proffered by the professional. Hence, whether one defines a situation as injurious can be a function of one's relative social power in an organization either defined by bureaucratic or professional status (Barley 1991, p. 181). Institutional theories of organizational power go one step further by underscoring how elite-enforced "conceptions of control" 
set the agenda for processes and outcomes of political contestations among organizational managers by demarcating the boundaries of legitimate conflict (Fligstein 1990, Ocasio \& Kim 1999).

ORGANIZATIONAL CULTURE Martin's (1992) multiperspective analysis of organizational culture provides a useful lens to examine how theory influences the study of covert conflict. She argues that organizational culture approaches emphasize "integrationist," "differentiation," or "fragmented" assumptions. Integrationist approaches prize organization-wide consensus that largely exclude dissent. Differentiation approaches (the literature on collective action in organizations resonates with this view) focus on subcultural conflicts that turn on overt, rather than covert, opposition. The study of covert conflict is therefore more likely in approaches based in fragmented assumptions that direct attention to how ambiguity veils dissent and blunts punishment. As long as researchers tacitly or explicitly draw from intergrationist or differentiation perspectives, covert conflict will be elided or ignored. In this sense, theories silence dissent.

\section{Field Level}

From the perspective of practice theory and institutionalist approaches, fields refer to social domains bounded by their expertise and legitimacy, distinctive interpersonal and interorganizational networks, hierarchical relationships, distributions of material resources, and institutional logics (Bourdieu \& Waquant 1992, pp. 94100; Friedland \& Alford 1991). To date, there has been relatively little systematic research that explains covert conflict at the field level. However, studies of other phenomena provide clues to the potential payoffs of this approach.

One such clue can be found in Jackall (1988), who notes that managers in large corporations use moral codes that vary across the fields in which their organizations operate. Such codes define appropriate conflict processes and issues as well as appropriate sources of authorities that can be mobilized to settle disputes within firms. Another clue with regards to the role of fields in covert conflict can be found in the literature on field change and emergence. Field-level changes can generate new formal structures and technologies that profoundly affect "the way business is done" within and across existing organizations (Fligstein 2001, Rao et al. 2000, Scott et al. 2000). Katzenstein's (1998) analysis of the impact of the women's movement on the U.S. military offers an illustration. She documents how the women's movement moved into multiple organizational fields and provided various kinds of material and symbolic resources to women that enabled them to take clandestine struggles to the front stage of military politics.

Yet another field-level approach can be found in Black (1993), who conceives of social fields as "geometries" of social and normative statuses, material resources, relational and network connections, and cultural properties that are associated with particular conflict forms and processes. This approach is intended as a general perspective on conflict, rather than only political conflict in organizations, and has been used to investigate interpersonal and intergroup conflict in a variety of settings 
(Baumgartner 1988, Cooney 1998), including organizations (Morrill 1995, Morrill et al. 1997, Tucker 1999). Within this tradition, Baumgartner (1984, p. 306) argues that covert political conflict—such as noncooperation and sabotage-is more likely in hierarchical social fields as the number and organization of aggrieved subordinates decrease. Senechal de al Roche (1996, 2001; see also Black 2002) observes that violent covert collective action, such as terrorism, thrives in polarized social fields where subordinates have long-standing grievances against their superiors, high solidarity, and a lack of ties to and extreme cultural distance from their superiors, and practice collective liability.

\section{Macro Level}

The restructuring of organizations and the emergence of transnational social movements compose a double-edged sword at the macro level with regard to covert political conflict in organizations. On the one hand, economic organizational restructuring of U.S. industries has altered traditional managerial ideologies and structures, as well as mass production processes (Smith 1990). On a global scale, restructuring has led to complex transnational networks of finance and governance as well as dispersals of organizations to far flung regions around the world (Davis \& McAdam 2000). Nongovernmental organizations outside of the corporate sphere have also proliferated across national boundaries to add to the complexity of transnational organizational networks (Boli \& Thomas 1999). Such conditions would seem conducive to decreased perceptions of control among organizational members of all statuses as sources of organizational authority are transferred to positions that appear ever more physically and politically remote from the locations where organizational work is conducted. Moreover, restructuring and globalization has meant the increasing flight of organizations from those countries with developed trade unions and other protections to those where organizational members have little or no experience with manufacturing and sparse histories of collective action within organizations (Ong 1987).

The other side of the macro coin is the emergence of transnational contentious politics constructed on social terrains built by states and linked to domestic political contention (Tarrow 2001). "Master" collective action frames that emphasize injustice and/or rights (Snow \& Benford 1992) and "rationalized" accounts for political action (Meyer et al. 1997) are also in play across a wide variety of contexts and issues. These developments can supply material resources, models of collective action, rhetorical language, and legitimacy for those engaged in covert political action in organizations that span great geographical and cultural distances (McAdam et al. 1996). They may even facilitate the conditions that transform covert action into overt voice.

\section{CONCLUSION}

We raise three orienting questions at the outset of this review. With regard to our first question, we argue that covert conflict encompasses four interrelated elements: contestation of institutionalized power and authority, perceptions of 
collective injury, social occlusion, and officially forbidden forms of dissent. To answer our next question, we discuss several variable features of covert conflict, including its material and symbolic forms, social visibility, collective dimensions, and outcomes. We then tackle existing explanations of covert political conflict by examining perspectives at the micro, organizational, field, and macro levels of analysis. Using our review as a point of departure, we end by discussing the implications the study of covert conflict holds for organizational analysis, social movement research, and avenues of future inquiry.

The analysis of covert political conflict deepens our understanding of the dark, informal side of organizations (Vaughan 1999). Rather than only characterizing covert political conflict as a source of deviance or irrational opportunistic behavior, many studies suggest that it can act as a mechanism through which subordinated and disenfranchised organizational members defend their dignity and challenge dominant categorizations (Lamont 2000). Some covert conflict, especially that which occurs at the tops of organizations among elites, can act as a direct "check" on institutionalized authority (e.g., Dalton 1959, Morrill 1995). Second, analyses of covert political conflict sensitizes researchers to less-visible "repertoires of contention" in organizations, as well as broader society, thus expanding sociological knowledge about how collective action and social movements can develop from and impact everyday life (e.g., McAdam et al. 2001). Such research also underscores the dynamic and, under some conditions, tenuous character of employee commitment to formal and informal organizational routines (Burawoy 1979, Collinson 1994). Finally, the study of covert conflict moves beyond perspectives of organizational change that emphasize managerially planned action, placing more emphasis on unplanned and unintended sources of change, especially from marginalized groups. Indeed, covert political conflict can draw from or activate informal social circuits of interaction and exchange (Zelizer 2003) in the pursuit of organizational change. Taken together, these points suggest the need to re-imagine forms of collective agency in organizations (and broader society) with respect to conflict, power, and change.

Our review also underscores the pressing need for the development of theoretical approaches that cut across and/or link multiple levels of analysis. Included here would be theory that explains the etiology and patterns of covert conflict in organizations. Frameworks from the social movements literature, such as Tarrow's (2001) research on mechanisms of transnational collective action, the work by Snow \& Benford (1992, Benford \& Snow 2000) on framing, or the perspective of McAdam et al. (2001) on contentious politics could all be refined for these purposes. Field approaches - either grounded in institutional and practice theories (Bourdieu \& Waquant 1992, pp. 94-100; Friedland \& Alford 1991; Stryker 2002) or the sociology of conflict (Black 1993) — may also provide sources for such theory. Finally, critical organization theory-including labor process theory (Jermier et al. 1994b), critical management studies (Alvesson \& Willmott 1992, Zald 2002), and feminist perspectives (Calas \& Smircich 1996, Martin 1990, Meyerson 2001)_offers yet another explanatory approach to covert conflict that cuts across 
the micro, organizational, field, and macro levels of analysis. Critical organization theorists resonate with micro perspectives that locate the origins of covert political opposition in frustration over social injustice in the workplace (Scully \& Segal 2002). Critical organization theorists also embed these frustrations in broader cultural schemas and social systems that systematically reproduce particular groups (e.g., women, ethnic minorities, gays and lesbians) in marginalized organizational positions and provide them with limited political voice.

Also needed are frameworks that directly link research on covert political conflict and other forms of collective action to contemporary organization theory. Relevant questions include the following: What kinds of organizational fields facilitate or constrain covert conflict within and across organizations? Under what conditions do covert tactics become legitimated or institutionalized (e.g., Powell \& DiMaggio 1991)? What roles does covert political conflict play in the delegitimization of existing or generation of new institutionalized organizational forms and fields (e.g., Powell \& Jones 2003, Rao et al. 2000)? How are organizational demographics, such as size, age, or inertia, related to the emergence and outcomes of covert political conflict (e.g., Carroll \& Hannan 2000)? What is the life course of covert tactics in particular organizational populations (e.g., Hannan \& Freeman 1989)?

The flip side of the coin is frameworks that directly link the study of covert conflict to contemporary social movement theory. Relevant questions along these lines might include the following: What is the relationship between societal social movements, organizational structures, and covert political conflict in organizations (e.g., Zald et al. 2002)? How do master collective action frames inform, enable, or constrain covert conflict in organizations (e.g., Benford \& Snow 2000)? How do political opportunities (i.e., the weakening of formal authority) and mobilizing structures (i.e., interpersonal relationships) in organizations influence the emergence and spread of covert political conflict (McAdam et al. 1996)? What is the relationship between covert political conflict and multiple, contending social movement agendas in organizations (e.g., Meyer \& Staggenborg 1996)?

These clusters of questions - whether oriented toward organizational or social movement analysis - suggest the importance of developing theoretically informed work not only on the emergence of covert political conflict in organizations, but also on its consequences. This is a thorny issue because collective action of all kinds is typically not monolithic such that linking causes with effects is difficult (Giugni 1999, Tilly 1999). Here it is important to consider how success attributed to covert political conflict is defined. One aspect of success certainly involves "extra movement consequences" that result in tangible changes to organizational structures, everyday routines, and cultures (Earl 2000). A related issue is Gamson's (1990) well-known empirical finding that violence and other disruptive tactics are associated with greater social movement success (e.g., state policy or legal change) than moderate tactics. Does this relationship hold for covert political violence in organizations? What are the unanticipated consequences of covert violence in organizations? 
Another way to define success relevant to covert political opposition is the emergence of coherent political voice. There may be multiple mechanisms that lead from covert conflict to overt voice, including the construction of networks that can be used for mobilization, the weakening of control systems and reduction in organizational health over long periods of time, and cultural readiness that enables collective action frames to resonate with potential participants. Other mechanisms include "brokerage" that links previously disconnected actors into new political identities or "modeling" that diffuses forms of covert collective action from one context to another (Tarrow 2001). At the same time, future research should address the relationship between vertical superior-subordinate conflicts and horizontal conflicts among subordinates (Gottfried \& Fasenfest 1984).

Finally, aside from theoretical innovation, we urge the development of new methods to study covert political conflict in organizations that complement the current emphasis on rich ethnographic and historical cases studies. Such innovation could include narrative analysis, critical perspectives, or factorial survey approaches that would shed light on the interpretive and decision-making processes related to covert political acts. Social network analysis could also illuminate the informal social structures that constrain, enable, or sustain covert conflict. Other approaches, such as event history analysis and diffusion studies, could help establish the central tendencies of covert conflict across diverse organizational and historical contexts.

\section{ACKNOWLEDGMENTS}

An earlier draft of this review was presented at the panel on New Directions in Organizational Theory at the Annual Meeting of the American Sociological Association in Chicago in 2002. We thank Mark Chaves, Elisabeth Clemens, Frank Dobbin, Jennifer Earl, Martha Feldman, Tim Hallett, Joanne Martin, Debra Meyerson, Michael Mulcahy, Wade Roberts, David Snow, Sidney Tarrow, Andrew H. Van De Ven, members of the Social Organization Seminar at the University of Arizona, members of the Organization Theory Seminar in Sociology at the University of California, Irvine, and an anonymous reviewer for helpful comments.

\section{The Annual Review of Sociology is online at http://soc.annualreviews.org}

\section{LITERATURE CITED}

Allen VL, Greenberger DB. 1980. Destruction and perceived control. In Advances in Environmental Psychology, ed. A Baum, JE Singer, pp. 85-109. Hillsdale, NJ: Earlbaum

Alvesson M, Willmott H. 1992. On the idea of emancipation in manager and organization studies. Acad. Manag. Rev. 17:432-64

Ammerman NT. 1990. Baptist Battles: Social
Change and Religious Conflict in the Southern Baptist Convention. New Brunswick, NJ: Rutgers Univ. Press

Arvey RD, Jones AP. 1985. The use of discipline in organizational settings: a framework for future research. Res. Organ. Behav. 7:367-408

Barley SR. 1991. Contextualizing conflict: 
notes on the anthropology of disputes and negotiations. In Research on Negotiation in Organizations, ed. MH Bazerman, RJ Lewicki, BH Sheppard, pp. 165-99. Greenwich, CT: JAI Press

Baumgartner MP. 1984. Social control from below. In Toward a General Theory of Social Control, Vol. 1: Fundamentals, ed. D Black, pp. 303-45. Orlando, FL: Academic

Baumgartner MP. 1988. The Moral Order of a Suburb. NY: Oxford Univ. Press

Bayat A. 1997. Un-civil society: the politics of the 'informal people.' Third World Q. 18:5372

Benford RD, Snow DA. 2000. Framing processes and social movements: an overview and assessment. Annu. Rev. Sociol. 26:61139

Bies RJ, Tripp TM. 1998. Two faces of the powerless: coping with tyranny in organizations. In Power and Influence in Organizations, ed. RM Kramer, MA Neal, pp. 203-19. Thousand Oaks, CA: Sage

Black D. 1993. The Social Structure of Right and Wrong. San Diego, CA: Academic

Black D. 2002. Terrorism as social control. Part I: The geometry of destruction. Am. Sociol. Assoc. Crime Law Deviance Newsl. Spring:3-5

Blum J. 1961. Lord and Peasant in Russia: From the Ninth to the Nineteenth Century. Princeton, NJ: Princeton Univ. Press

Boli J, Thomas GM, eds. 1999. Constructing World Culture: International NonGovernmental Organizations Since 1875. Stanford, CA: Stanford Univ. Press

Bourdieu P, Wacquant LJD. 1992. An Invitation to Reflexive Sociology. Chicago: Univ. Chicago Press

Brehm J, Gates S. 1997. Working, Shirking, and Sabotage: Bureaucratic Response to a Democratic Public. Ann Arbor, MI: Univ. Michigan Press

Brown G. 1977. Sabotage: A Study of Industrial Conflict. Nottingham, Engl.: Spokesman Books

Burawoy M. 1979. Manufacturing Consent: Changes in the Labor Process Un- der Monopoly Capitalism. Chicago: Univ. Chicago Press

Burns T. 1955. The reference of conduct in small groups: cliques and cabals in occupational milieux. Hum. Relat. 8:467-86

Burns T. 1961. Micro-politics: mechanisms of institutional change. Admin. Sci. Q. 3:25781

Calas MB, Smircich L. 1996. From 'the woman's point of view': feminist approaches to organization studies. In Handbook of Organization Studies, ed. S Klegg, C Hardy, WR Nord, pp. 218-57. London: Sage

Carroll GT, Hannan MT. 2000. The Demography of Corporations and Industries. Princeton, NJ: Princeton Univ. Press

Clarke J. 1988. Presidential address on the importance of understanding organizational conflict. Soc. Q. 29:149-61

Chaves M. 1997. Ordaining Women: Culture and Conflict in Religious Organizations. Cambridge, MA: Harvard Univ. Press

Clemens ES. 1997. The People's Lobby: Organizational Innovation and the Rise of Interest Group Politics in the United States, 18901925. Chicago: Univ. Chicago Press

Cohen S, Taylor L. 1993. Escape Attempts: The Theory and Practice of Resistance in Everyday Life. London: Routledge. 2nd ed.

Cooney M. 1998. Warriors and Peacemakers: How Third Parties Shape Violence. NY: NYU Press

Colburn F. 1989. Foot dragging and other peasant responses to the Nicaraguan revolution. In Everyday Forms of Peasant Resistance, ed. FD Colburn, pp. 175-97. Armonk, NY: M.E. Sharpe

Collinson D. 1994. Strategies of resistance: power, knowledge and subjectivity in the workplace. See Jermier, Knights, Nord 1994b, pp. 25-68

Cressey DR. 1953. Other People's Money: A Study in the Social Psychology of Embezzlement. Glencoe, IL: Free Press

Crino MD, Leap TL. 1988. Sabotage: Protecting your company means dealing with the dark side of human nature. Success 35:5255 
Curtius M. 1998. Sure, workers get mad, but more getting even. Los Angeles Times, Oct. 31, p. C1

Dalton M. 1959. Men Who Manage: Fusions of Feeling and Theory in Administration. NY: Wiley

Davis GF, McAdam D. 2000. Corporations, classes, and social movements after managerialism. Res. Organ. Behav. 22:193-236

Davis GF, Thompson A. 1994. A social movement perspective on corporate control. Admin. Sci. Q. 39:141-73

Ditton J. 1976. Moral horror versus folk terror: output restriction, class, and the social organization of exploitation. Sociol. Rev. 24:51944

Ditton J. 1977. Perks, pilferage, and the fiddle: the historical structure of invisible wages. Theory Soc. 4: 39-71

Ditton J. 1979. Baking time. Soc. Rev. 27:15767

Dowding K, John P, Mergoupis T, Van Vugt M. 2000. Exit, voice and loyalty: analytic and empirical developments. Eur. J. Polit. Res. 37:469-95

Dubois P. 1979. Sabotage in Industry. Hammondsworth, Engl.: Penguin Books

Earl J. 2000. Methods, movements, and outcomes: methodological difficulties in the study of extra-movement outcomes. Res. Soc. Mov. Confl. Change 22:3-25

Edwards PK, Scullion H. 1982. The Social Organization of Industrial Conflict: Control and Resistance in the Workplace. Oxford: Basil Blackwell

Edwards R. 1982. Contested Terrain: The Transformation of the Workplace in the Twentieth Century. NY: Basic Books

Eldridge JET. 1968. Industrial Disputes. London: Routlege \& Kegan Paul

Emerson RE, Messinger SL. 1977. The micropolitics of trouble. Soc. Probl. 25:121-34

Farrell D. 1983. Exit, voice, loyalty, and neglect as responses to job dissatisfaction: a multidimensional scaling study. Acad. Manag. $J$. 26:596-606

Farrell D, Rusbult CE. 1992. Exploring the exit voice, loyalty, and neglect typology: the in- fluence of job satisfaction, quality of alternatives, and investment size. Empl. Responsib. Rights J. 5:201-18

Felstiner WLF, Abel RL, Sarat A. 1980/1981. The emergence and transformation of disputes: naming, claiming, and blaming. Law \& Soc. Rev. 15:631-54

Fennell D. 1976. Beneath the surface. Radic. Am. 10:15-29

Fligstein N. 1990. The Transformation of Corporate Control. Cambridge, MA: Harvard Univ. Press

Fligstein N. 2001. Social skill and the theory of fields. Soc. Theory 19:105-25

Friedland R, Alford RA. 1991. Bringing society back in: symbols, practices, and institutional contradictions. In The New Institutionalism in Organizational Analysis, ed. WW Powell, PJ DiMaggio, pp. 232-63. Chicago: Univ. Chicago Press

Gamson WA. 1990. The Strategy of Social Protest. Belmont, CA: Wadsworth. 2nd ed.

Gialcone RA, Greenberg J, eds. 1997. AntiSocial Behavior in Organizations. Thousand Oaks, CA: Sage

Gialcone RA, Knouse SB. 1990. Identifying wrongful employee behavior: the role of personality in organizational sabotage. J. Bus. Ethics 9:55-61

Gilliom J. 1997. Everyday surveillance, everyday resistance: computer monitoring in the lives of the Appalachian poor. In Studies in Law Politics and Society, Vol. 16, ed. A Sarat, S. Silbey, pp. 275-97. Greenwich, CT: JAI Press

Giugni M. 1999. How social movements matter: past research, present problems, future problems. In How Social Movements Matter, ed. M Giugni, D McAdam, C Tilly, pp. xiii-xxxiii. Minneapolis, MN: Univ. Minn. Press

Goffman E. 1962. Asylums: Essays on the Social Situation of Mental Patients and Other Inmates. Garden City, NY: Anchor Books

Goffman E. 1967. Interaction Ritual: Essays on Face-to-Face Behavior. NY: Pantheon Books

Gottfried H. 1994. Learning the score: the duality of control and everyday resistance 
in temporary-help service industry. See Jermier, Knights, Nord 1994b, pp. 102-27

Gottfried H, Fasenfest D. 1984. The role of gender in class formation: A case of female clerical workers. Rev. Radic. Polit. Econ. 16:89104

Gouldner AW. 1954. Patterns of Industrial Democracy. New York: Free Press

Greenberger D, Strasser S, Cummings L, Dunham R. 1989. The impact of personal control on performance and satisfaction. Organ. Behav. Hum. Decis. Processes 43:29-51

Greenhalgh L. 1987. Interpersonal conflict in organizations. In International Review of Industrial and Organizational Psychology, ed. CL Cooper, LT Robertson, pp. 229-71. NY: Wiley

Gross JT. 1979. Polish Society Under German Occupation: The Generalgouvernement, 1939-1944. Princeton, NJ: Princeton Univ. Press

Guha R. 1989. Saboteurs in the forest: Colonialism and peasant resistance in the Indian Himalaya. In Everyday Forms of Peasant Resistance, ed. FD Colburn, pp. 64-92. Armonk, NY: M.E. Sharpe

Haldeman HR. 1994. The Haldeman Diaries: Inside the Nixon White House. NY: G.P. Putnam's

Hall J. 1952. Theft, Law, and Society. Indianapolis, IN: Bobbs-Merrill

Hannan MT, Freeman JF. 1989. Organizational Ecology. Cambridge, MA: Harvard Univ. Press

Hanawalt BA. 1979. Crime and Conflict in English Communities, 1300-1348. Cambridge, MA: Harvard Univ. Press

Hebdon RP, Stern RN. 1998. Tradeoffs among expressions of industrial conflict: Public sector strike bans and grievance arbitrations. Ind Labor Relat. Rev. 51:204-21

Hirschman AO. 1970. Exit, Voice, \& Loyalty. Cambridge, MA: Harvard Univ. Press

Hirschman AO. 1993. Exit, voice, and the fate of the German Democratic Republican essay in conceptual history. World Polit. 45:173-202

Hodson R. 1991. The active worker: compli- ance and autonomy at the workplace. J. Contemp. Ethnogr. 20:47-78

Hollinger RC, Clark JP. 1982. Employee deviance: a response to the perceived quality of the work experience. Soc. Q. 23:333-43

Howkins A. 1977. Structural conflict and the farm worker: Norfolk, 1900-1920. J. Peasant Stud. 4:217-29

Jackall R. 1988. Moral Mazes: The World of Corporate Managers. NY: Oxford Univ. Press

Jermier J. 1983. Labor process control in modern organizations: subtle effects of structure. J. Bus. Res. 11:317-32

Jermier J. 1988. Sabotage at work: a rational view. In Research in the Sociology of Organizations, ed. N DiTomaso, SB Bacharach, pp. 101-34. Greenwich, CT: JAI Press

Jermier J, Knights D, Nord WR. 1994a. Resistance and power in organizations: agency, subjectivity and the labor process. See Jermier, Knights, Nord 1994b, pp. 1-24

Jermier J, Knights D, Nord WR, eds. 1994b. Resistance and Power in Organizations. London: Routledge

Kanter RM. 1977. Men and Women of the Corporation. NY: Basic Books

Katzenstein MF. 1998. Faithful and Fearless: Moving Feminist Protest Inside the Church and the Military. Princeton, NJ: Princeton Univ. Press

King R. 1978. In the sanding booth at Ford. In Social Problems in Today's World, ed. J Perry, E Perry, pp. 199-205. Boston: Little, Brown

Knights D, McCabe D. 1998a. When "life is but a dream": obliterating politics through business process re-engineering? Hum. Relat. 51:761-98

Knights D, McCabe D. 1998b. What happens when the phone goes wild? Staff, stress and spaces for escape in a BPR telephone banking work regime. J. Manag. Stud. 35:16394

Kochanowicz J. 1989. Between submission and violence: peasant resistance in the Polish manorial economy of the Eighteenth century. In Everyday Forms of Peasant Resistance, 
FD Colburn, ed. pp. 33-63. Armonk, NY: M.E. Sharpe

Kolb DM. 1987. Corporate ombudsmen and organizational conflict. J. Confl. Resolut. 31:673-92

Kolb DM, Putnam LL. 1992. Introduction: The dialectics of disputing. In Hidden Conflict in Organizations: Uncovering Behind-theScenes Disputes, ed. DM Kolb, JM Bartunek, pp. 1-31. Thousand Oaks, CA: Sage

Kunda G. 1992. Engineering Culture: Control and Commitment in a High-Tech Corporation. Philadelphia, PA: Temple Univ. Press

Kurzman C. 1998. Organizational opportunity and social movement mobilization: a comparative analysis of four religious movements. Mobilization 3:23-49

Lammers C. 1969. Strikes and mutinies: a comparative study of organizational conflicts between rulers and ruled. Admin. Sci. $Q$. 14:558-72

Lamont M. 2000. The Dignity of Working Men: Morality and the Boundaries of Race, Class, and Immigration. Cambridge, MA and NY: Harvard Univ. Press and Russell Sage Found.

LaNuez D, Jermier JM. 1994. Sabotage by managers and technocrats: Neglected patterns of resistance at work. In Resistance and Power in Organizations, ed. JM Jermier, D Knights, WR Nord, pp. 219-51. London: Routledge

Lewis IO. 1971. Ecstatic Religion: An Anthropological Study of Spirit Possession and Shamanism. Harmondsworth, Engl.: Penguin

Mahmood CK. 2001. Terrorism, myth and the power of ethnographic praxis. J. Contemp. Ethnogr. 20:520-45

Martin J. 1990. Deconstructing organizational taboos: the suppression of gender conflict in organizations. Organ. Sci. 4:339-59

Martin J. 1992. Cultures in Organizations: Three Perspectives. NY: Oxford Univ. Press

Martin J, Meyerson D. 1997. Executive women at Link.com [Teaching Cases]. Cambridge, MA: Harvard Bus. Sch. Press

Martin J, Meyerson D. 1999. Women and power: conformity, resistance, and disorganized coaction. In Power and Influence in Organizations, ed. RM Kramer, MA Neale, pp. 311-48. Thousand Oaks, CA: Sage

Mars G. 1974. Dock pilferage. In Deviance and Social Control, ed. P Rock, M McIntosh, pp. 209-228. London: Tavistock

Mars G. 1982. Cheats at Work: An Anthropology of Workplace Crime. London: George Allen \& Unwin

McAdam D, McCarthy JD, Zald MN. 1996. Introduction: opportunities, mobilizing structures, and framing processes-toward a synthetic, comparative perspective on social movements. In Comparative Perspectives on Social Movements: Political Opportunities, Mobilizing Structures, and Cultural Framings, ed. D McAdam, JD McCarthy, MN Zald, pp. 1-20. Cambridge, UK: Cambridge Univ. Press

McAdam D, Tarrow S, Tilly C. 2001. Dynamics of Contention. Cambridge, UK: Cambridge Univ. Press

McCann MW. 1994. Rights at Work: Pay Equity and the Politics of Legal Mobilization. Chicago: Univ. Chicago Press

Mechanic D. 1962. Sources of power in lower participants in complex organizations. Am.J. Sociol. 7:349-64

Merry SE 1982 Rethinking gossip and scandal. In Toward a General Theory of Social Control, Volume 1: Fundamentals, ed. D Black, pp. 271-302. Orlando, Fl: Academic

Meyer DS, Staggenborg S. 1996. Movements, countermovements, and the structure of political opportunity. Am. J. Sociol. 101:162860

Meyer JW, Boli J, Thomas GM, Ramirez FM. 1997. World society and nation state. Am. J. Sociol. 103:144-81

Meyerson DE. 2001. Tempered Radicals: How People Use Difference to Inspire Change at Work. Boston: Harvard Bus. School Press

Meyerson DE, Scully M. 1995. Tempered radicalism and the politics of ambivalence and change. Organ. Sci. 6:585-600

Molstad C. 1986. Choosing and coping with boring work. Urban Life 15:215-36 
Morgon ES. 1966. The Puritan Family: Religion and Domestic Relations in SeventeenthCentury New England. New York: Harper \& Row

Morrill C. 1991. The customs of conflict management among corporate executives. Am. Anthropol. 94: 871-93

Morrill C. 1995. The Executive Way: Conflict Management in Corporations. Chicago: Univ. Chicago Press

Morrill C. 2003. Institutional change through interstitial emergence: the growth of alternative dispute resolution in American law, 1965-1995. In How Institutions Change, ed. WW Powell. Chicago: Univ. Chicago Press. In press

Morrill C, Snyderman E, Dawson E. 1997. It's not what you do, but who you are: informal social control, social status, and normative seriousness in organizations. Sociol. Forum 12:519-43

Morrill C, Owen-Smith J. 2002. The rise of environmental conflict resolution: Subversive stories and the construction of collective action frames and organizational fields. In Organizations, Policy, and the Natural Environment: Institutional and Strategic Perspectives, ed. M Ventresca, A Hoffman, pp. 90-119. Stanford, CA: Stanford Univ. Press

Nader L. 1980. Alternatives to the American judicial system. In No Access to Law: Alternatives to the American Judicial System, ed. L Nader, pp. 3-55. NY: Academic

Ocasio W, Kim H. 1999. The circulation of corporate control: selection of functional backgrounds of new CEOs in large U.S. manufacturing firms, 1981-1992. Admin. Sci. $Q$. 44:532-562

Ong A. 1987. The Spirits of Resistance and Capitalist Discipline: Factory Women in Malaysia. Albany, NY: SUNY Press

Paules GF. 1991. Dishing it Out: Power and Resistance Among Waitresses in a New Jersey Restaurant. Philadelphia: Temple Univ. Press

Petigrew A. 1973. The Politics of Organizational Decision-Making. London: Tavistock
Pfeffer J. 1981. Power in Organizations. Boston: Pitman

Powell WW, DiMaggio PJ, eds. 1991. The New Institutionalism in Organizational Analysis. Chicago: Univ. Chicago Press

Powell WW, Jones D, ed. 2003. How Institutions Change. Chicago: Univ. Chicago Press. In press

Prasad A, Pushkala P. 1998. Everyday struggles at the workplace: The nature and implications of routine resistance in contemporary organizations. Res. Sociol. Organ. 15:225-57

Rao H. 1998. Caveat emptor: the construction of nonprofit consumer watchdog organizations. Am. J. Sociol. 103:912-61

Rao H, Morrill C, Zald MN. 2000. Power plays: how social movements and collective action create new organizational forms. Res. Organ. Behav. 22:237-81

Rockwell J. 1974. The Danish peasant village. J. Peasant. Stud. 1:409-61

Rochon TR. 1997. Culture Moves: Ideas, Activism, and Changing Values. Princeton, NJ: Princeton Univ. Press

Rusbult C, Lowery D. 1985. When bureaucrats get the blues: responses to dissatisfaction among federal employees. J. Appl. Soc. Pyschol. 15:80-103

Rusbult C, Farrell D, Rogers G, Mainous AG III. 1988. Impact of exchange variables on exit, voice, loyalty, and neglect: an integrative model of responses to declining job satisfaction. Acad. Manag. Rev. 31:599-627

Sapsford D, Turnbull P. 1994. Strikes and industrial conflict in Britain's docks: balloons or icebergs? Oxford Bull. Econ. Stat. 56:249-65

Scott JC. 1989. Everyday forms of resistance. In Everyday Forms of Peasant Resistance, FD Colburn, ed. pp. 3-33. Armonk, NY: M.E. Sharpe

Scott JC. 1990. Domination and the Arts of Resistance: Hidden Transcripts. New Haven, CT: Yale Univ. Press

Scott WR, Ruef M, Mendel PJ, Caronna C. 2000. Institutional Change and Healthcare Organizations: From Professional Dominance to Managerial Care. Chicago: Univ. Chicago Press 
Scully M, Segal A. 2002. Passion with an umbrella: grassroots activists in the workplace. Soc. Struct. Organ. Revisit. 19:125-68

Senechal de la Roche R. 1996. Collective violence as social control. Soc. Forces 11:97128

Senechal de la Roche R. 2001. Why is collective violence collective? Soc. Theory 19:126-44

Smith V. 1990. Managing in the Corporate Interest: Control and Resistance in an American Bank. Berkeley, CA: Univ. Calif. Press

Snow DA. 2002. Social movements as challenges to authority: resistance to an merging conceptual hegemony. Auth. Contention, Collect. Behav./Soc. Mov. Conf., Notre Dame Univ., South Bend, Indiana

Snow DA, Benford RD. 1992. Master frames and cycles of protest. In Frontiers in Social Movement Theory, AD Morris, CM Mueller, pp. 133-55. New Haven, CT: Yale Univ. Press

Soeters JL. 1986. Excellent companies as social movements. J. Manag. Stud. 23: 299-312

Spector PE. 1975. Relationships of organizational frustration with reported behavioral reactions of employees. J. Appl. Psychol. 60:635-37

Stephenson K. 1990. The emergence of virtual groups. Ethnology 29:279-96

Sotirin P, Gottfried H. 1999. The ambivalent dynamics of secretarial 'bitching': control, resistance, and the construction of identity. Organization 6:57-80

Stryker R. 2002. A political approach to organizations and institutions. Res. Sociol. Organ. 19:171-93

Tarrow S. 2001. Transnational politics: contention and institutions in international politics. Annu. Rev. Polit. Sci. 4:1-20

Taylor L, Walton P. 1971. Industrial sabotage: motives and meanings. In Images of Deviance, ed. S Cohen. pp. 219-45. Harmondsworth, Engl.: Penguin Books

Thomas K, ed. 1999. The Oxford Book of Work. Oxford, Engl.: Oxford Univ. Press

Thompson WE. 1983. Hanging tongues: a sociological encounter with the assembly line. Qual. Sociol. 6:215-37
Tilly C. 1999. Conclusion: From interactions to outcomes in social movements. In How Social Movements Matter, ed. M Giugni, D McAdam, C Tilly, pp. 253-70. Minneapolis, MN: Univ. Minn. Press

Tobias JJ. 1972. Crime in Industrial Society in the Nineteenth Century. Harmondsworth, Engl.: Penguin

Tucker J. 1989. Employee theft as social control. Deviant Behav. 10:319-34

Tucker J. 1993. Everyday forms of employee resistance: how temporary workers handle conflict with their employers. Soc. Forum 8:2545

Tucker J. 1999. The Therapeutic Corporation. NY: Oxford Univ. Press

Van Mannen J. 1992. Drinking our troubles away: managing conflict in British police agency. In Hidden Conflict in Organizations: Uncovering Behind-the-Scenes Disputes, ed. DM Kolb, JM Bartunek, pp. 32-62. Thousand Oaks, CA: Sage

Vaughan D. 1999. The dark side of organizations: mistake, conduct, and disaster. Annu. Rev. Sociol. 25:271-305

Vinzant C. 2000. Messing with the boss's head. Fortune, May 1, pp. 329-31

Watson B. 1971. Counter-planning on the shop floor. Radic. Am. 5:77-85

Willis R. 1986. White-collar crime: the threat from within. Manag. Rev. 5:22-32

Wittek R, Wielers R. 1998. Gossip in organizations. Comput. Math. Organ. Theory 4:189204

Zald MN. 1970. Organizational Change: The Political Economy of the YMCA. Chicago: Univ. Chicago Press

Zald MN. 2002. Spinning disciplines: critical management studies in the context of the transformation of management education. Organization 9:365-85

Zald MN, Berger MA. 1978. Social movements in organizations: Coup d'etat, insurgency, and mass movements. Am. J. Sociol. 83:82361

Zald MN, Morrill C, Rao H. 2002. How do social movements penetrate organizations? Environmental impact and organizational 
response. Michigan Conf. Organ. Theory/ Soc. Mov. Theory, Ann Arbor

Zelizer VA. 2003. Circuits within capitalism. In

The Economic Sociology of Capitalism, ed. V Nee, R Swedberg. Cambridge, UK: Cambridge Univ. Press
Zeitlin LR. 1971. A little larceny can do a lot for employee morale. Psychology Today 5:2226, 64

Zhou X. 1992. Unorganized interests and collective action in communist China. Am. Soc. Rev. 58:54-73 